\title{
Significance between Organizational Culture and Lecturer Performance of Private Universities in Medan
}

\author{
Nur Aisyah ${ }^{1}$, Biner Ambarita ${ }^{2}$, Abdul Muin Sibuea ${ }^{2}$ \\ ${ }^{1}$ Ph.D Student in State University of Medan (Unimed), Medan, Indonesia \\ ${ }^{2}$ Lecturer in State University of Medan (Unimed), Medan, Indonesia \\ aisyah415@yahoo.co.id
}

\begin{abstract}
This study discusses about how significance between organizational culture and lecturer perfomance. This research is a study that uses numerical numbers and changes feed approach to quantitative methods, with descriptive research that processes data with SPSS from the results of questionnaires on population samples. The research is done in private universities, college, academies and polytechnics in Medan. The result shows that organizational culture tends to be "high" (57.78\%), only $36.83 \%$ which distributes the average value into sufficient categories.
\end{abstract}

Keywords : organizational culture; lecturer perfomance; private universities

\section{Introduction}

Educator certification which is given to lecturers through the certification process is a formal proof of recognition of lecturers as professionals at the tertiary level. Serdos is based on online and digitally integrated which shows lecturer data in supporting lecturers' career development and academic cultural values and has honesty values in the context of character education in higher education. Whereas the assessment carried out is based on the performance of the lecturer in carrying out the development of higher education tridharma and evaluating contributions to the basic competencies of the lecturer which include social competence as indicated by English language skills, academic potential, and scientific publications in national and international journals. The role of the assignment of a lecturer contained in the performance of the lecturer is shown by the responsibility of educating the nation's life and improving the quality of Indonesian people. A competent lecturer is one who has lecturer performance in the field of higher education tridharma, and as a form of profession is given a formal lecturer certification / certification certification recognized by the government.

Income in the financial sector of lecturers will increase beyond the costs incurred by the university's tridharma at each university, such as teaching lecturers' fees, lecturers' fees guiding / testing students and other positions in the lecturers' structural position. The performance of lecturers in this study is from the observations of researchers about how a private lecturer made himself to follow competitively about the track record of lecturers in implementing the tridharma of higher education, this is different from lecturers at state universities. This difference is motivated by the interpersonal differences in the provisions and regulations that apply between private universities and state universities.

Government issued regulations indicated by more significant differences are the abilities possessed by private lecturers with cognitive abilities towards educator functional positions, namely in evaluating each track record and expertise, characteristics that are interpersonal of the lecturer and lecturer ethics held by private lecturers. In permanent lecturers, the government assumes more periodically on a period of time to increase the position of public lecturers' functions. In the increase of functional positions, permanent lecturers of PTS follow regulations that change in each academic development. Fundamental 
changes are contained in the anatomy of regulatory regulations that are binding on the provisions and systems issued by the government, including how to obtain formal recognition from the government which makes a permanent lecturer in PTS having an educator certification. Lecturer certification is a pay of performance recognized by the government and given in accordance with the functional position of the lecturer who has the certification of the lecturer.

Pay of performance is a payment for performance results. According to Luthans (2006: 157-158) that "human resources with scientific professionals individually and in teams. Then individually will be given a number of awards in the form of payment for performance results, namely: (1) commission; (2) appreciation for leadership; (3) appreciation of the results of new targets created; (4) income from team knowledge; (5) income from expertise; (6) income from competence and (7) change and target flexibility. Almost the same as what was stated in the educator certification presented in this study, which is the income generated by the results of expertise and competency results of technology-based lecturers in an integrated manner."

\section{Review of Literature}

\subsection{Lecturer Perfomance}

Understanding value in performance is something that is valuable, quality, shows quality, and is useful for humans. Something that is valuable means that something is valuable or useful for human life. The characteristics of values contained in the characteristics of values according to Bambang Daroeso are as follows: (a) the value is an abstract reality and exists in human life. Abstract values cannot be sensed, which can be observed are only valuable objects. For example, people who have honesty. Honesty is a value, but we cannot sense honesty, (b) Values have a normative nature, meaning values contain hopes, ideals, and a necessity so that values have an ideal nature (das sollen). Value is manifested in the form of norms as a human foundation in acting. For example, the value of justice. Everyone hopes and gets and behaves that reflects the value of justice; (c) Value functions as a motivator and humans are supporters of value. Humans act on a basis and are driven by values they believe in. For example, the value of piety. The existence of this value makes everyone motivated to be able to reach the degree of piety.

According to Robbins, $(2013 ; 589)$ that performance (type of performance) consists of 1) task performance that is performance based on the task by implementing it with responsibility; 2) citizenship, which is the action caused by citizenship behavior by contributing to the psychological environment and 3) counterproductivity, which is counteract to actions and actively. Whereas in determining performance, Colquit's (2013; 541-544) performance evaluation is needed, namely identifying training and development needs focusing on human resource skills and competencies. Performance criteria that are evaluated include individual task outcomes / results of work or performance of individuals, behavior and traits that exist in human resources so that it produces a work performance / performance. Work performance / performance $(2013 ; 51)$ is a set of human resource behaviors that contribute to the achievement of organizational tasks through 3 (three) dimensions, namely: assignments, citizenship behavior and counterproductive behavior. Task performance includes human resource behavior that is directly involved in transforming 
organizational resources into goods or services produced by the organization, for example routine task performance, adaptive task performance and creative task performance.

Robbin $(2015$; 40-41) further states that to get high performance, roles management is needed, namely interpersonal roles, informational roles and decisional roles owned by human resources by improving management skills, technical skills, human skills and conceptual skills so that owned basic competencies to be able to compete professionally. The development of knowledge is complemented by increasing management activities in accordance with globalization and increasingly evolving technologies, especially improvements to traditional management, communication, human resources management and networking. Individual performance is defined as the individual's ability to do something with expertise in a particular field. The attitude of responsible individuals will gain achievements in terms of intellectuals. Sequence or sequence of performance activities by Armstrong and Baron. The organization's mission and organizational strategic goals are the starting point of the performance process. The mission and strategic objectives are used as a reference for the level of management below. The formulation of the organization's strategic mission and objectives is aimed at ensuring that every subsequent activity must be in line with these objectives and expected to contribute to achievement. Along with the opinion above Withmore stated that performance is an expression of a person's potential in fulfilling his responsibilities by setting certain standards. To increase optimum performance it is necessary to set clear standards, which can be a reference for all employees. Performance will be created if the human resources can carry out their responsibilities to the maximum possible. Such an idea was also expressed by Haynes who said that building performance expectations needs to pay attention to four main elements, namely; (1) job description, which will describe the duties and responsibilities of a position, so that officials who will do it know exactly what to do and how to do it, (2) the results field with clear performance indicators, meaning indicators of success of their tasks must be known , (3) performance standards, indicate the success or failure of the tasks carried out, and (4) objectives, with the implementation of these three elements systematically, it is expected that the stated objectives will be achieved. The four elements remind you that you will work sincerely without looking back on the work.

\subsection{Organizational Culture}

Cultural values are defined as channels of trust about proper statements or declining ways in the given culture, the influence of expressions on one's behavior. In Robbins said that organizational culture is the values, beliefs and basic principles that are the basis of management systems and practices and behaviors that enhance and strengthen these principles. According to Robbins (2013: 213) that "Organizational culture has been described as share values, principles, traditions, and ways of doing things that influence organizational behavior and that distinguishes organizational from other organizations. In most organizations, these shared values and practices have evolved over time, and to a large extent, how things are done around here. Organizational culture has been described as values, principles, traditions, and ways of doing things that affect the way members of an organization act and that distinguish organizations from other organizations. Most organizations, shared values and practices have evolved over time.

According to Colquit (2013: 538-539) that "organizational culture is shared social knowledge in an organization regarding rules, norms and values that shape the attitudes and 
behavior of these employees. There are three (3) components of organizational culture, namely observable artifacts, espoused values and underlying assumptions. Observed artifacts include symbols, physical structures, languages, stories, rituals and ceremonies. Suitability of organizational compatibility concerns the value and personality of a person according to the culture of organizational practice. Organizational suitability has a weak positive effect on performance and a strong positive effect on organizational commitment. "While Robbins (2013: 319) mentions "organizational culture is interpreted as a basic philosophy that provides direction for organizational policies in the management of employees and customers". Robbins further stated that a system of shared meaning was formed by its citizens who at the same time became a differentiator with other organizations. From some of the definitions above, we can conclude that organizational culture is a value system that is believed and can be learned, can be applied and developed continuously, an assumption that is owned, implicitly accepted by the group and determining how the group feels, thinks, and react to its diverse environment. Culture reflects the values and beliefs held by members of the organization. These values tend to last for a long time and are more resistant to change.

From some of the definitions above, we can conclude that organizational culture is a value system that is believed and can be learned, can be applied and developed continuously, an assumption that is owned, implicitly accepted by the group and determining how the group feels, thinks, and react to its diverse environment. Culture reflects the values and beliefs held by members of the organization. These values tend to last for a long time and are more resistant to change. Organizational culture also functions as an adhesive, unifying, identity, image, brand, motivator, development that is different from other organizations that can be learned and passed on to the next generation, and can be used as a reference for human behavior in goal-oriented organizations. or the results / targets set. Organization as a place or place where people gather, cooperate rationally and systematically, planned, organized, guided and controlled, in utilizing organizational resources (money, material, machinery, methods, environment, facilities, infrastructure, data, etc.) in a manner efficient and effective to achieve predetermined goals. The intended cooperation is cooperation aimed at achieving goals.

This directed collaboration is carried out by following patterns of interaction between individuals or groups. The interaction pattern is harmonized with various rules, norms, beliefs, certain values as determined by the founders of the organization. The whole pattern of interaction in a certain time will form a habit together or shape the organizational culture. Organizational culture as a study feels its importance to be explored and developed in all types of organizations. In essence it is the basic values of the organization, which will act as a foundation for attitude, behavior and action for all members of the organization. Organizational culture in detail is as soft side and hard side in it includes structural, production systems, technology and design. It is illustrated that it is not possible to apply advanced technology not supported by an adequate (cultural) mindset. Organizational value is a bridge or intermediary between basic assumptions and artifacts. Organization is a value system that is believed by all members of the organization, which is studied, applied and developed continuously and serves as an adhesive and is used as a reference in behaving. 


\section{Research Method}

This research uses numerical numbers and changes feed approach to quantitative methods, with descriptive research that processes data with SPSS from the results of questionnaires on population samples, so as to get a significant relationship and mutual tendency to the probability of errors in the hypotheses built.

The research is done in private universities, college, academies and polytechnics in Medan city in Kopertis Region I of North Sumatra Province, because the university is a complex PTS with a diversity of study programs and many lecturers of private universities so this study only examines and analyze research at the level of private universities in the city of Medan. This research takes universities as populations because homogeneously has the same characteristics in managing university activities. Based on the number in North Sumatra Region I Kopertis in 2016/2017 there were 23 private universities in the form of Universities, as in table 3.1. This research is not the same as the previous research, especially the dissertation that already exists in the education management of Postgraduate Unimed S3 (State University of Medan). In this study, what is interesting is the performance of PTS lecturers who are influenced by human resources themselves, through factors that influence performance lecturers, including factors related to cognitive abilities, organizational culture and factors related to individual characteristics, and related to work ethics. Lecturer performance has a big influence on the quality legality of higher education, both internally and externally.

\section{Discussion}

The organizational culture variable data $\left(\mathrm{X}_{1}\right)$ consists of six indicators: 1$)$ members act as initiators and contributors, 2) having relevant skills 3) individual reliability 4) team interactions, 5) team cohesion and 6) work team commitment. The organizational culture variable (X1) data is 315 . The following is the distribution and level of inclination of organizational culture data in the table below:

Table 1. Frequency Distribution of Organizational Culture Score

\begin{tabular}{|c|l|l|l|}
\hline Class & Class Interval & F. Absolute & F. Relative (\%) \\
\hline 1 & $86-90$ & 10 & 3,17 \\
\hline 2 & $91-95$ & 45 & 14,29 \\
\hline 3 & $96-100$ & 61 & 19,37 \\
\hline 4 & $101-105$ & 75 & 23,81 \\
\hline 5 & $106-110$ & 49 & 15,56 \\
\hline 6 & $111-115$ & 39 & 12,38 \\
\hline 7 & $116-120$ & 19 & 6,03 \\
\hline 8 & $121-125$ & 16 & 5,08 \\
\hline 9 & $126-130$ & 1 & 0,32 \\
\hline Total & 315 & 100 \\
\hline
\end{tabular}


Table 1 shows that the average score of 103.99 is in the $4^{\text {th }}$ inverval class with respondents as many as 75 people or $23.81 \%$. This means that from 315 respondents there were 116 people or $36.83 \%$ who had scores below the average and as many as 124 respondents or $39.37 \%$ who had scores above the average. To see whether the data is normally distributed or not, a frequency histogram can be used as shown in figure 1 below:

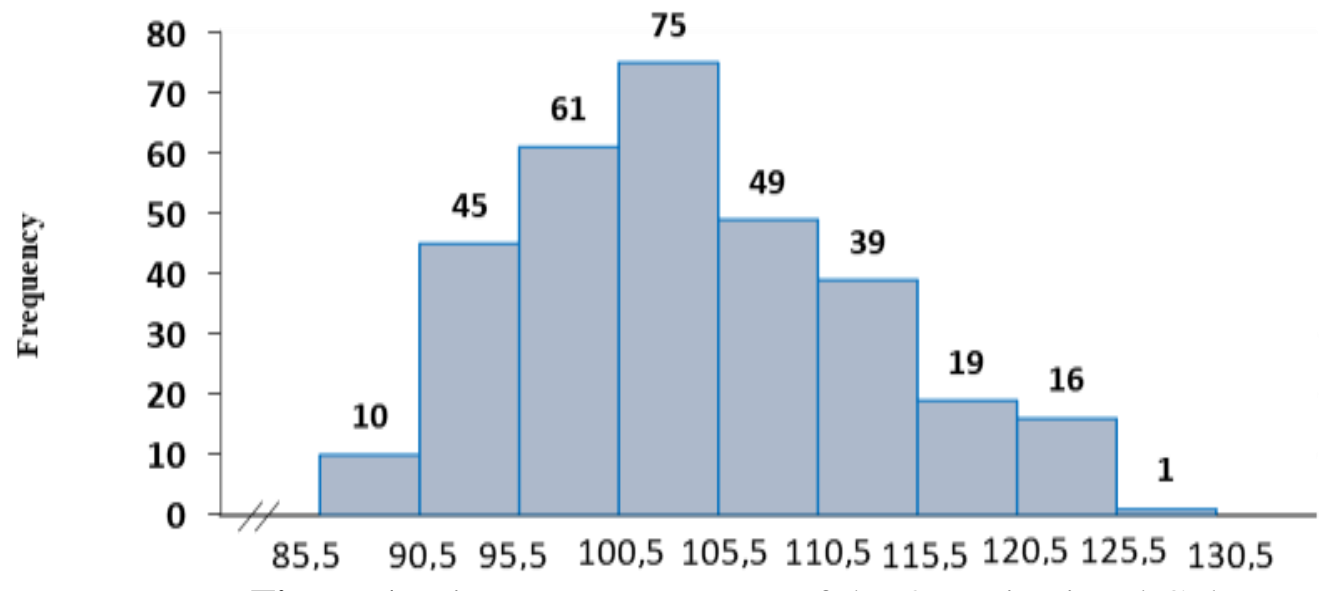

Figure 1. Histogram Frequency of the Organizational Culture

The frequency histogram image influences the quality of organizational culture data is done by comparing the average and standard deviation of the empirical score with the average and the ideal standard deviation score. The lowest score of empirical data is known to be 86 and the highest score is 128 and the average score of empirical data is 103.99. While the ideal maximum score is 150 and the ideal minimum score is 30 , so the ideal average score is $1 / 2(150+30)=90$ and the ideal standard deviation is $1 / 6(150-30)=20$. Thus based on the results of these calculations it is known that the average empirical score (103.99) is higher than the ideal average score of (90).

Data netted from 30 items answered by 315 respondents indicated variation in some of the answer choices. From the choices of respondents' answers, a calculation is then based on the category classification formula. The results of the tendency of respondents 'answers about organizational culture and the recapitulation of the tendency of respondents' answers through the following table 2:

Table 2. Criteria for Classification Calculation Results in Variables in Organizational Culture

\begin{tabular}{|l|l|c|l|l|}
\hline No & Score Range $\mathbf{X}_{\mathbf{2}}$ & $\begin{array}{l}\text { Cumulative } \\
\text { Frequency }\end{array}$ & $\begin{array}{l}\text { Relative } \\
\text { Frequency } \\
(\boldsymbol{\%})\end{array}$ & Category \\
\hline 1 & $\mathrm{X} \geq 120$ & 17 & 5,40 & Very High \\
\hline 2 & $100 \leq \mathrm{X}<120$ & 182 & 57,78 & High \\
\hline 3 & $80 \leq \mathrm{X}<100$ & 116 & 36,83 & Standard \\
\hline 4 & $60 \leq \mathrm{X}<80$ & 0 & 0,0 & Low \\
\hline 5 & $\mathrm{X}<60$ & 0 & 0,0 & Very Low \\
\hline
\end{tabular}


The data in Table 2 above shows that as many as $5.40 \%$ of respondents stated that organizational culture is very high. A total of $57.78 \%$ of respondents stated that the organizational culture is in a high range, as many as $36.83 \%$ of respondents stated that the organizational culture was sufficient and the rest did not represent a low organizational culture. Distribution of empirical scores for statements Organizational culture spreads between the lowest scores of 86 to the highest score of 128. Thus it is concluded that respondents' scores on organizational culture tend to be high.

Lecturer performance variable data $\left(\mathrm{X}_{5}\right)$ consists of four indicators, namely 1$)$ the task of conducting education and teaching, 2) the task of conducting research and development of scientific work, 3) the task of doing community service and 4) tri dharma tertiary support assignments. The following is presented the distribution of data and the trend level of lecturer performance data as follows:

Data distribution and frequency distribution of lecturer performance variable scores can be seen in Table 3 below:

Table 3. Frequency Distribution of Lecturer Performance Assessment Scores

\begin{tabular}{|c|c|c|c|}
\hline Class & Class Interval & F.Absolute & F.Relative (\%) \\
\hline 1 & $79-83$ & 10 & 3,17 \\
\hline 2 & $84-88$ & 17 & 5,40 \\
\hline 3 & $89-93$ & 50 & 15,87 \\
\hline 4 & $94-98$ & 55 & 17,46 \\
\hline 5 & $99-103$ & 69 & 21,90 \\
\hline 6 & $104-108$ & 57 & 18,10 \\
\hline 7 & $109-113$ & 36 & 11,43 \\
\hline 8 & $114-118$ & 11 & 3,49 \\
\hline 9 & $119-123$ & 10 & 3,17 \\
\hline Total & & 315 & 100,00 \\
\hline
\end{tabular}

Table 3 shows that the average score of 100.45 is in the interval 5 class with 69 respondents or $21.90 \%$. This means that from 315 respondents there were 132 people or $41.90 \%$ who had scores below the average and as many as 114 respondents or $36.19 \%$ who had scores above the average. To see whether the data is normally distributed or not, a frequency histogram can be used as shown in figure 4.5 below:

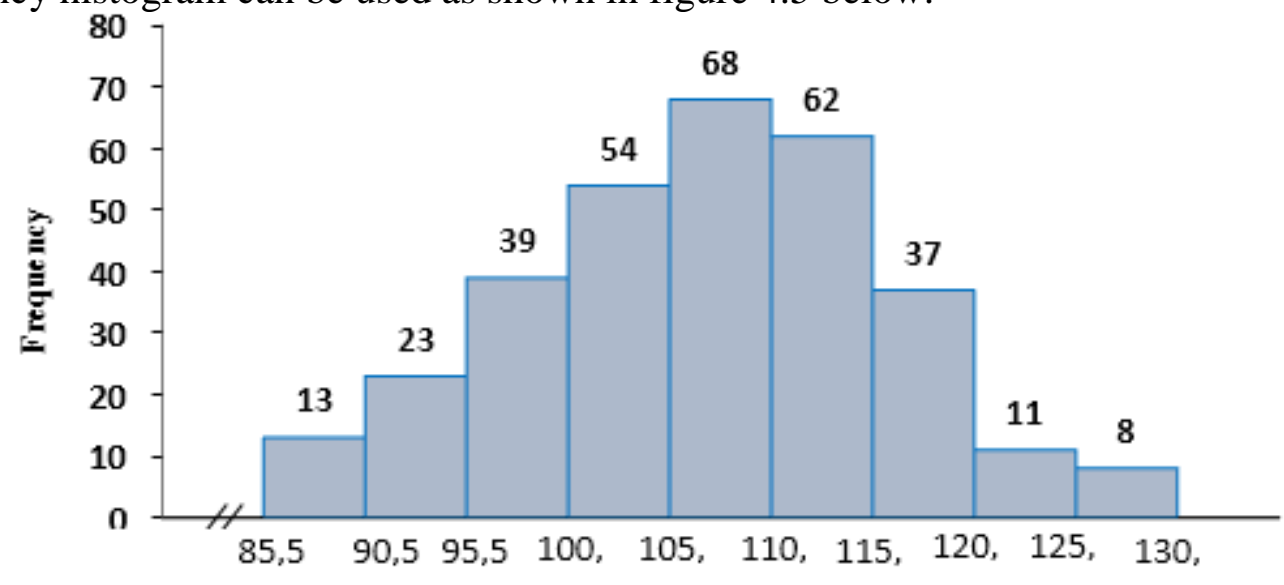

Figure 2. Histogram of Frequency of Lecturer Performance 
The figure of frequency histogram above shows data tends to be normally distributed. Whereas to determine the quality of lecturer performance data can be done by comparing the average and standard deviation of the empirical score with the average and the ideal standard deviation score. The lowest score of empirical data is known to be 79 and the highest score is 123 and the average empirical data score is 100.45 . While the ideal maximum score is 128 and the ideal minimum score is 32 , so the average ideal score is $1 / 2(128+32)=80$ and the ideal standard deviation is $1 / 6(128-32)=16$. Thus based on results The calculation shows that the average empirical score (104.45) is higher than the average ideal score of (80). This finding can be interpreted that the performance of lecturers is categorized as good

Data netted from 30 items answered by 315 respondents indicated variation in some of the answer choices. From the choices of respondents' answers, a calculation is then based on the category classification formula. The results of the tendencies of respondents 'answers about the performance of the lecturers and the recapitulation of the tendency of respondents' answers through Table 6:

Table 4. Criteria for Calculation of Classification of Variable Categories Lecturer Performance

\begin{tabular}{|l|l|l|l|l|}
\hline No & Score Range $\mathbf{X}_{3}$ & $\begin{array}{l}\text { Cumulative } \\
\text { Frequency }\end{array}$ & $\begin{array}{l}\text { Relative } \\
\text { Frequency } \\
(\boldsymbol{\%})\end{array}$ & Category \\
\hline 1 & 04 & 103 & 32,70 & Very High \\
\hline 2 & $88 \leq \mathrm{X}<104$ & 192 & 60,95 & High \\
\hline 3 & $72 \leq \mathrm{X}<88$ & 20 & 6,35 & Standard \\
\hline 4 & $56 \leq \mathrm{X}<72$ & 0 & 0,00 & Low \\
\hline 5 & $\mathrm{X}<56$ & 0 & 0,00 & Very Low \\
\hline
\end{tabular}

The data in Table 6 above shows that as many as $32.70 \%$ of respondents stated that the performance of lecturers was very high, as many as $60.95 \%$ of respondents indicated that the performance of lecturers was high, as many as $6.35 \%$ of respondents stated that lecturers' performance was sufficient and no respondents stated lecturers are in the low category. The distribution of empirical scores for the assessment of lecturer performance spreads between the lowest scores of 79 to the highest score of 123. Thus it is concluded that the respondents' scores on the performance of lecturers tend to be high.

\subsection{Lilliefors Test of Lecturer Performance Variables on Organizational Culture}

The results of calculations in Appendix 9 obtained the largest $\mathrm{L}_{0} 0.0474$, with $\mathrm{N}=315$ and a real level of $5 \%$ from the list of tables obtained $\mathrm{L}_{\text {table }}=0.0500$. Because $\mathrm{L}_{0}<\mathrm{L}_{\text {table }}$ $(0.0474<0.0500)$ then $\mathrm{H}_{0}$ is accepted so it is concluded that the sample comes from a population that is normally distributed.

\subsection{Homogeneity Test of Variants in Lecturer Performance (X5) based on data on Organizational Culture (X2)}

The results of the calculation in Appendix 10 are obtained $\chi^{2}=47.58$. While the price of $\chi_{\text {tabel }}^{2}$ table with $\mathrm{dk}=40$ at a significant level of $5 \%$ of 55.76 . Therefore $\chi^{2}$ hitung $<\chi^{2}$ table $(47.58$ 
$<55.76)$ then $\mathrm{H}_{0}$ is accepted so it is concluded that the population has a homogeneous variance.

\subsection{Linearity Test and Meaning of Regression of Lecturer Performance on Organizational Culture}

The regression equation of the Lecturer Performance variable $\left(\mathrm{X}_{5}\right)$ for organizational culture $\left(\mathrm{X}_{2}\right)$ is $(\mathrm{X}) \hat{5}=21,555+0,759 \mathrm{X} 2$. A summary of the results of the calculation of the regression equation is presented in the following table 4.20:

Table 5. Summary of ANAVA for $X_{5}$ Regression Equations on $X_{2}$

\begin{tabular}{|l|l|l|l|l|l|}
\hline Source of Variance & $\mathrm{Dk}$ & $\mathrm{JK}$ & $\mathrm{RJK}$ & $\mathrm{F}_{\mathrm{h}}$ & $\mathrm{F}_{\mathrm{t}(0,05)}$ \\
\hline Total & 315 & 3203364 & - & & \\
\hline Regression (a) & 1 & 3178464,013 & - & & \\
Regression (b/a) & 1 & 13964,561 & 13964,561 & 399,702 & 3,87 \\
Residue (sisa) & 313 & 10935,427 & 34,937 & & \\
\hline Tuna Suitable & 39 & 1733,806 & 44,457 & \multirow{2}{*}{1,340} & \multirow{2}{*}{1,443} \\
Error & 274 & 9087,679 & 33,167 & & \\
\hline
\end{tabular}

From the results of linearity regression test results obtained results 1.309 . By consulting $\mathrm{F}_{\text {count }}$ with $\mathrm{F}_{\text {table }}$ with the level of $0.05 \mathrm{dk}=\mathrm{K}-2(\mathrm{db}=39)$ as the numerator, and $(\mathrm{dk}=274)$ as the denominator, obtained Ftable $=1,443$. Then obtained $\mathrm{F}_{\text {count }}<\mathrm{F}_{\text {table }}(1.309<1.443)$ so that it can be concluded that the regression equation: $\mathrm{X} 5=21.555+0.759 \mathrm{X} 2$ is linear.

From the results of the regression equation significance test the results are 399,702. From the distribution table Ftable with a level of $0.05 \mathrm{dk}=1: 313=3.87$. By consulting Fcount to Ftable with $\mathrm{dk}=1: 313$, the price of $\mathrm{F}_{\text {count }}<\mathrm{F}_{\text {table }}$ (399.702 $>3.87$ ) can be concluded that the regression coefficient means.

The results of the correlation calculation between organizational culture and lecturer performance indicate the price of the correlation coefficient of $r_{25}=0.749$. From the criticism price table at the significance level of $5 \%$ with the number $n=315, r_{\text {table }}=0.111$. Thus the price of $r_{25}>r_{\text {table }}(0.749>0.111)$, it can be said that there is a significant correlation between the variables of organizational culture and the performance of lecturers.

With the magnitude of $\mathrm{r} 25=0.749$ calculated the significance number of the variable cognitive cognitive correlation with Lecturer Performance was tested by t test, resulting in $\mathrm{t}_{\text {count }}=19.993$. From the distribution list $\mathrm{t}$ with $\mathrm{dk}=313$ and the $5 \%$ significance level obtained $t$ table $=1.968$. Thus it turns out that $t_{\text {count }}>t_{\text {table }}(19.993>1.968)$ so that it can be concluded that there is a meaningful correlation between organizational culture variables with Lecturer Performance.

The hypothesis proposed is:

$\rho_{52}$ : Organizational culture $\left(\mathrm{X}_{2}\right)$ on lecturer performance $\left(\mathrm{X}_{5}\right)$.

$\mathrm{H}_{0}: \rho_{52}=0$

$\mathrm{H}_{1}: \rho_{52} \neq 0$

The testing criteria are $\mathrm{H} 0$ rejected if $t_{c}>t_{t}(0.05)$. The amount of $t_{t}(0.05 ; 315)$ is 1.968 . This hypothesis states that there is a direct and positive influence of organizational culture (X2) on DOI : https://doi.org/10.33258/birci.v2i2.239 
bored performance with a coefficient $\rho_{52}=0.553$. The price of an individual test calculation shows the price of $t_{c}$ at 18,562 . Thus $t_{c}>t_{t}(18,562>1,968)$, so that $H_{0}$ is rejected, the coefficient of organizational culture path $\left(\mathrm{X}_{2}\right)$ on the performance of lecturers can be stated to be significant. Thus, it can be said that organizational culture has a direct and positive influence on the performance of permanent lecturers in private universities in Medan.

Table 6. Summary of Direct and Indirect Effects on $\mathrm{X}_{5}$

\begin{tabular}{|l|c|l|l|l|l|}
\hline \multirow{2}{*}{ Variable } & \multirow{2}{*}{$R$} & \multicolumn{3}{|c|}{ Effect / Influence } & \multirow{2}{*}{ Non-Effect } \\
\cline { 3 - 5 } & & Direct & Indirect & Total & \\
\hline $\mathrm{X}_{2}$ & 0,824 & 0,553 & 0,075 & 0,628 & 0,120 \\
\hline
\end{tabular}

Organizational culture variable $\left(\mathrm{X}_{2}\right)$ has a direct influence on lecturer performance of 0.553 . Based on the results of the descriptive analysis, a total of $4.76 \%$ respondents stated that organizational culture was very high. As many as $58.10 \%$ of respondents stated that organizational culture is in a high range, $37.14 \%$ of respondents stated that organizational culture was sufficient. The average value of the overall cultural organization of lecturers in private universities in Medan is 103.96. The results of this study explain that organizational culture needs to be further enhanced by increasing personal attention, charisma, intellectual development, and also idealized attributes.

The results showed that the effect of exogenous variables on organizational culture on the endogenous variable of lecturer performance was 0.553 . Thus the structural equation predicts that $\mathrm{X}_{5}=0.553 \mathrm{X} 2$. If it is assumed that the influence of other variables remains, it can be concluded that the increase in one unit of organizational culture will be able to increase 0.553 lecturer performance units. In other words the results of the analysis provide information that to improve lecturer performance can be done by increasing the organizational culture of lecturers in private universities in Medan.

Then the results of this study are also supported by Bass theory (in Wagimo, 2015; 116) defining organizational culture based on the influence and relationship of leaders with followers or subordinates. The followers feel trust, admiration, loyalty and respect for leaders, and have high commitment and motivation for achievement and higher performance. Luthans further stated that organizational culture brings a condition towards high performance in organizations that face the demands of renewal and change.

In the Mamang research journal, et al. (2013: 12) concluded that the study also found a direct effect of organizational culture on the performance of lecturers, in the results of the study concluded that lecturer performance was influenced by variables greater than indirect influence through job satisfaction on lecturer performance. According to Marwan (2016: 259) lecturer performance is influenced by organizational culture, leadership behavior, achievement motivation and job satisfaction by using proportional random sampling techniques, that lecturer performance is high.

The results showed that the effect of exogenous variables on organizational culture on endogenous variables of lecturer's work ethics was 0.285 . Influence outside the path 0.324 . Thus the structural equation predicts that $\mathrm{X}_{4}=0.285 \mathrm{X} 2$. If it is assumed that the influence of other variables remains, it can be concluded that the increase in one unit of organizational culture will be able to increase 0.285 units of work ethics for lecturers. In other words, the DOI : https://doi.org/10.33258/birci.v2i2.239 
results of the analysis provide information that to improve the work ethics of lecturers, it can be done by increasing the organizational culture of permanent lecturers in private universities in Medan.

Furthermore, according to Wijaya's theory, the notion of organizational culture style is a leader who is able to bring about changes in each individual involved and for all organizations to achieve higher performance (in Saputro, 2015: 3).

\section{Conclusion}

Based on the results of descriptive data analysis, organizational culture tends to be "high" (57.78\%), only 36.83\% which distributes the average value into sufficient categories. Based on the results of testing the research hypothesis and discussion, organizational culture has a direct effect on the performance of permanent lecturers in private universities in Medan. In other words, the better the organizational culture, the higher the performance of permanent lecturers in private universities in Medan. Organizational culture has a positive direct effect on the performance of lecturers with indicators acting as initiators, having skills, individual reliability, team interaction, team cohesion and commitment of the work team chosen as an indicator that can see the organizational culture within a higher education institution in Medan.

\section{References}

Absah,Yeni. (2007). Pengaruh Kemampuan Pembelajaran Organisasi Terhadap Kompetensi, Tingkat Diversifikasi Dan Kinerja Perguruan Tinggi Swasta Di Sumatera Utara. Disertasi, Pascasarjana, Surabaya, Universitas Airlangga.

Ace Suryadi. (2014). Pendidikan Indonesia Menuju 2025. Outlook: Permasalahan, Tantangan \& Alternatif Kebijakan. Bandung: Remaja Rosdakarya.

Amstrong, Michael. (1999. Manajemen Sumber Daya Manusia; Judul Asli: A Handbook of Human Resources Management. Terjemahan Sofyan Cikrat dan Haryanto, Jakarta, Elex Media Komputindo.

Anderson, C.R. (1997). Locus of Control, Coping Behaviors, and Performance in a Stress Setting longitudinal Study. Journal of Applied Psychology.

Arikunto, Suharsimi. (1993). Manajemen Pengajaran Secara Manusia. Jakarta: PT. Rineka Cipta.

Ambarita, Biner. (2010). Pengaruh Kepemimpinan, Manajemen Personalia, Budaya Organisasi, Kepuasan Kerja, dan Komitmen Organisasi Terhadap Kinerja Dosen di Universitas Negeri Medan. Disertasi, Medan : Program Pascasarjana Universitas Negeri Medan.

Ayudiati, S.E. (2010). Analisis Pengaruh Locus of Control Terhadap Kinerja Dengan Etika Kerja Islam Sebagai Variabel Moderating (Studi Pada Karyawan Tetap Bank Jateng Semarang). Thesis,(unpublished), Semarang, Universitas Diponegoro.

Arfida BR. (2003). Ekonomi Sumber Daya Manusia. Jakarta, PT, Ghalia Indonesia.

Azwar.S. (2008). Penyusunan Skala Psikologi, Jakarta.

Barsalou,L.W. (2003). Situated simulation in the human conceptual system, Language and 


\section{Cognitive Processes.}

Bangun, Ramon. Theresia , Linda. (2018). The Influence of Culture, Job Satisfaction and Motivation

Becher, Brian, M. Huselid and D. Ulrich. (2001). The HR Scorecard Linking People, Strategy and Performance.Boston: Havard Business School Press.

Boyatzis A.R. (1982). The Competent Manager: A Model for Effective Performance. New York, John Wiley \&Sons, Inc.

Campbell, Kevin. (2002). Ownership Structure and The Operating Performance oh Hungarian Firms. Working Paper.

Cartwright,N. (1999). Models and the limits of theory Quantum Hamiltons and the BCS modelsuper conductivity in models as mediator. Cambridge, university press.

Cascio, Wayne F. ( 2013 ). Managing Human Resources. Colorado,Mc Graw -Hill

Chaston I., B. Badger and E.S. Sadler. (2000). Organizational Learning Style and Competences. GroupOrganizational Learning Development Centre. Plymouth Business School, University of Playmouth, UK.

Cita D.J. and E.R. Benjamin. (1998). Competency-Based Pay: A Concept in Evolution Compensation and Benefit Review, September-Oktober.

C. A. O' Reilly. (1989). Corporation Culture, and Comitment : Motivation and Social Control in Organization. California Management Review, Vol. 31, No 4.

Colquitt, Jason A., Lepine, Jeffry A., and Wesson, Michael J. (2009). Organizational Behavior. Improving Performance and Commitment in the Workplace. New York, McGraw-Hill.

Corsini, Ali. And A.J. Marsella. (1983). Personality Theories: Research and Assesment. USA, University ofHawai at Manoa-Peacock Published, Inc.

Dale, Margaret. (2003). Developing Management Skills, Techniques For Improving Learning Performance, Jakarta: Penerbit Gramedia.

Dede Mariana. (2007). Pengaruh Budaya Organisasi Terhadap Perilaku Pejabat Publik (Studi Pada Pemerintah Provinsi Jawa Barat). Disertasi Program PascaSarjana Unpad Bandung.

DuBrin, Andrew J. 2010. Principle of Leadership sixth Edition. Nelson Education,Ltd,Canada.

Feryal, C. (2010). Student Teachers Perceptions of Teacher Competence and Their Attributins for Successand Failure in Learning. Uluslararası Sosyal Arastırmalar Dergisi. The Journal of International Social Research, Volume 3 / 10.

Endang Abdullah. (2007). Pengaruh Budaya Organisasi Pendidikan Formal, Motif dan Kreativitas Terhadap Kinerja Pejabat Birokrat. Disertasi UPI Bandung .

Endah, Setyowati. (2002). Pengembangan SDM Berbasis Kompetensi, Solusi untuk Meningkatkan Kinerja Organisasi. Jurnal Ekonomi \& Bisnis, Volume IV,No.1, September.

Fred N Kerlinger. (2004). Asas-asas Penelitian Behavioral. Terjemahan Landung Yogyakarta : Gadjah Mada University Press.

Friedman, H.H., L.W. Friedman and S. Pollack. (2005). Transforming a University from a Teaching Organization to a Learning Organization. Review od Business.

Gana, Ali Baba. (2011). The Effect of Motivation on Workers Perfromance (A case Study of Maiduguriflour Mill Ltd. Borno State, Nigeria). Continental J. Social Sciences, 
Willolud Journal 4 (2), ISSN: 2141-4265, p. 8-13.

George, Jennifer M, Gareth R. Jones. (2006). Contemporary Management: Creating Value in Organizations ( Fourth Edition). USA: McGraw-Hill.

Ghozali, L. (2001). Aplikasi Analisis Multivariate Dengan Program SPSS. Semarang: Badan Penerbit Universitas Diponegoro.

Gibson L.James, John M.Ivancevich, James H.Donnelly,Jr., Robert Konopaske. (2012). Organizational Behaviour, The McGraw-hill Companies Inc.

Goleman, Daniel. (2002). Emotional Intelegence-Kecerdasan Emosional. Terjemahan Alex Tri Kancoro Widodo. Jakarta: PT. Gramedia.

Hornby, D. and R. Thomas. (1989). Towards a Better Standard of Management. Personnel Management, Vol.21No.1, pp.52-55, Pan, London.

Harbour, Jerry L. (1997). Performance Measurement. Oregon: Productivity Press.

Hasibuan, Malayu SP. (2003). Manajemen Sumber Daya Manusia. Edisi Revisi, Jakarta: PT Bumi Aksara.

Handoko, dkk. (2015). Internasional Journal of Business and Management Invention. ISSN (Online):2319 - 8028, ISSN (Print): 2319 - 801X www.ijbmi.org Volume 2 Issue 12 December. 201XI, Organizational Culture, Job Satisfaction, Organizational Commitment, the Effect on Lecturer Performance.

Irawati, Ira. (2009). Pengaruh Internalisasi Budaya Organisasi Terhadap Kinerja Juru Penilik Jalan (Baanschouer) di PT Kereta Api Daerah Operasi 2 Bandung. Program PascaSarjana Unpad Bandung : Disertasi.

Irawan Prasetya., Sudani Motik., dan Sri Wahyu Kridasakti. (1997). Manajemen Sumber Daya Manusia. Jakarta: STIA LAN.

Indriantoro, Nur dkk. (2002). Metodologi Penelitian Bisnis. BPFE, Yogyakarta.

Indiyani, dkk. (2016). Personality as a determinant of the performance of lecturers. I J A B E R. Vol. 14, No. 10 (2016): 6165-61800.

Ismail Nawawi Uha. (2015). Budaya Organisasi, Kepemimpinan \& Kinerja Proses terbentuk, Tumbuh Kembang, Dinamika dan Kinerja Organisasi. Prenamedia Group. Jakarta.

Ivancevich M,John dkk. (2007). Perilaku dan Manajemen Organisasi, Jilid 1,Edisi Ketujuh. Jakarta: Erlangga.

Marion E. Haynes (1986). Management Performance A Comprehension Guide to Effective Supervision. California Liferime Learning Publication. California.

Marwan. (2016). Pengaruh budaya organisasi, perilaku kepemimpinan, motivasi berprestasi, kepuasan kerja terhadap kinerja dosen perguruan tinggi swasta di provinsi Aceh.

Mathis, Robert L, John H Jackson. (2006). Human Resource Management, terjemahan, Edisi Kesepuluh, Jakarta, Salemba Empat.

Mamang, dkk. (2013). The Effect of Organizational Culture On lecturers' Job Statisfaction and Performance (A research in Muhammadiyah University throughout East Java). International Journal of Learning Development ISSN 2160-4063 2013, Vol 3, No. 3

Mulyadi. (2007). Sistem Perencanaan dan Pengendalian Manajemen. Jakarta, Salemba Empat.

Mursini. (2012). Pengaruh komunikasi pimpinan tingkat program studi , efektifitas tim, motivasi kerja, dan Etika terhadap Kinerja Dosen Unimed. Disertasi.

Musafir. (2007). Pengaruh Kemampuan dan Motivasi Terhadap Kinerja Pegawai Pemerintah Provinsi Gorontalo. Jurnal Ikhsan Gorontalo, Nomor 3, Volume 2. 
Rahmawati, Enny, Y. Warella dan Zaenal Hidayat. (2006). Pengaruh Motivasi Kerja, Kemampuan Kerja dan Gaya Kepemimpinan terhadap Kinerja Karyawan pada Badan Kesatuan Bangsa dan Perlindungan Masayarakat Provinsi Jawa Tengah. Dialogue, Jurnal Ilmu Administrasi dan Kebijakan Publik, Vol. 3 No. 1, Januari.

Reed, Stephen K. (2010). Cognition Theories and Applications $8^{\text {th }}$ Edition. Pre-press PMG, Belmont, USA.

Restu. (2013). Pengaruh budaya organisasi, kepemimpinan transformasional, kepribadian, kepuasan kerja dan motivasi berprestasi terhadap kinerja.

Rivai, Veithzl, Masri Mohd dkk. (2008). Performance Appraisal Sistem yang tepat untuk menilai kinerja karyawan dan Meningkatkan Daya Saing Perusahaan. Edisi Kedua. Jakarta: Rajawali Press.

Robbins dan Mary Coulter. (2007). Mangement. New Jersey: Pearson Prentice Hall.

Robbin, P, Stephen dan Timothy A Judge. (2008). Perilaku Organisasi Jilid I dan II Terjemahan, Edisi 12. Jakarta: Penerbit Salemba Empat.

Sumantri, Suryana (2001). Perilaku Organisasi. Bandung: Universitas Padjajaran.

Tissen, Rene., Andriessen, Daniel., and Deprez, Frank Lekanne. (1998). Value Based Knowledge Management, Nederland: Addison Wesley Long.

Trisnaningsih, dkk. (2013). Dancing with Diversities Local Multiparadigm Accounting Research (Methodology) Orchestra the factors that influence to lecturers performance with motivation as an intervening variable, journal.

Umar H. (2002). Metode Riset Bisnis. Jakarta: PT.Gramedia Pustaka Utama.

Wibowo. (2007). Manajemen Kinerja.RajaGrafindo Persada. Jakarta.

Yulk. Kenneth N. Wexley dan Gary A. (1977). Organizational Behavior and Personnel Psychology. Illinois. Richard D. Irwin, Inc.Illionis.

Yuyun. Fajriani, dkk. (2013). Pengaruh Gaya Kepemimpinan Kepala Sekolah dan Etos Kerja Guru terhadap kinerja Guru. Universitas Sebelas Maret.

Peraturan Menteri Pendidikan dan Kebudayaan Republik Indonesia. (2014). Petunjuk Teknik Pelaksanaan Penilaian Angka Kredit Jabtan Fungsional Dosen.

PerMenpan \& RB no.46. (2013). jo no. 17 Tahun 2013 Lampiran I s/d VI http://forlap.dikti.go.id

Hadiantini (2017:237)

Zuhri (2015:1091) 